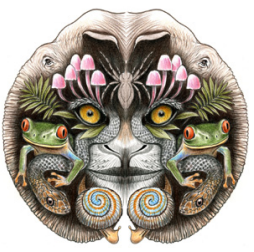

ISSN 0974-7907 (Online) ISSN 0974-7893 (Print)

OPEN ACCESS

\title{
A NEW SPECIES OF LISSODYNERUS GIORDANI SOIKA (HYMENOPTERA: VESPIDAE: EUMENINAE) FROM RUTLAND ISLAND, SOUTHERN ANDAMAN, INDIA
}

\author{
P. Girish Kumar ${ }^{1}$, G. Srinivasan ${ }^{2} \&$ J.M. Carpenter ${ }^{3}$
}

\author{
1,2 Zoological Survey of India, M-Block, New Alipore, Kolkata, West Bengal 700053, India \\ ${ }^{3}$ Division of Invertebrate Zoology, American Museum of Natural History, Central Park West at $79^{\text {th }}$ Street, \\ New York, NY 10024, USA \\ ${ }^{1}$ kpgiris@gmail.com (corresponding author), ${ }^{2}$ zsisamy@rediffmail.com, ${ }^{3}$ carpente@amnh.org
}

Abstract: Lissodynerus rutlandicus sp. nov. is described from Rutland Island, southern Andaman, India. A checklist of the world species of Lissodynerus is also provided.

Keywords: Checklist, Eumeninae, Lissodynerus, new species, Vespidae.

Abbreviations: $\mathrm{H}$ - Head; $\mathrm{M}$ - Mesosoma; OOL - Ocellocular distance; POL - Post ocellar distance; S2 - Metasomal sternum 2; T1-T5 Metasomal terga 1-5.

Lissodynerus is an Oriental and Australian genus of potter wasps. Sixteen species with eight additional subspecies are recorded worldwide, of which one species with one additional subspecies, namely $L$. septemfasciatus feanus (Soika, 1941) and $L$. septemfasciatus septemfasciatus (Smith, 1858), are recorded from the Indian subcontinent. In this paper a new species, namely Lissodynerus rutlandicus is described from Rutland Island of southern Andaman, India, and compared with its most similar described species. A taxonomic account of the genus Lissodynerus and a world checklist of the species are also provided.

\section{MATERIAL AND METHODS}

The specimens were studied and photographed using a Leica Stereo microscope with LAS software version 3.6.0. The types of the new species described are deposited in the 'National Zoological Collections' of the Zoological Survey of India, Kolkata (NZC). All efforts to collect more specimens of this new species by field collection did not succeed.

\section{Lissodynerus rutlandicus sp. nov.} (Images 1-6)

urn:Isid:zoobank.org:act:784CCE10-24AE-4610-AB3F-78DF8847737C

Material examined: Holotype: NZC 14878/H3, 23.xii.2013, male, Kumara Teri $\left(13^{\circ} 09^{\prime} 35.9^{\prime \prime} \mathrm{N}\right.$ \& 92 $\left.{ }^{\circ} 57^{\prime} 03.3^{\prime \prime} \mathrm{E}\right)$, Mancharie Jetty, Rutland Island, southern Andaman, India, coll. G. Srinivasan \& Party.

Diagnosis: Clypeus deeply emarginated at apex; T1 with regular and distinctly strong transverse carina and with a very narrow apical lamella; T2-T5 with broad, thick, opaque, brown apical lamella, with almost uniform width laterally and dorsally; upper carina of propodeum

DOI: http://dx.doi.org/10.11609/JoTT.04022.7664-7 | ZooBank: urn:Isid:zoobank.org:pub:79A1E32D-A53A-40C5-A10B-D5A73F549981

Editor: Bolívar R. Garcete-Barrett, FACEN, Universidad Nacional de Asunción, San Lorenzo, Paraguay.

Date of publication: 26 August 2015 (online \& print)

Manuscript details: Ms \# 04022 | Received 07 May 2014 | Final received 01 April 2015 | Finally accepted 12 August 2015

Citation: P. Girish Kumar, G. Srinivasan \& J.M. Carpenter (2015). A new species of Lissodynerus Giordani Soika (Hymenoptera: Vespidae: Eumeninae) from Rutland Island, southern Andaman, India. Journal of Threatened Taxa 7(10): 7664-7667; http://dx.doi.org/10.11609/JoTT.04022.7664-7

Copyright: (c) Kumar et al. 2015. Creative Commons Attribution 4.0 International License. JoTT allows unrestricted use of this article in any medium, reproduction and distribution by providing adequate credit to the authors and the source of publication.

Funding: Ministry of Environment, Forests \& Climate Change, Govt. of India, New Delhi.

Competing interests: The authors declare no competing interests.
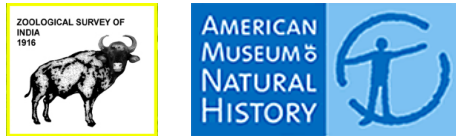

Acknowledgements: Authors are grateful to Dr. K. Venkataraman, Director, Zoological Survey of India, Kolkata, for providing facilities and encouragements. GS is thankful to Dr. C. Ragunathan, Scientist-C \& Officer-in-Charge, Andaman \& Nicobar Regional Centre of Zoological Survey of India, Port Blair for his help during the survey. PGK is also grateful to Dr. Kailash Chandra, Scientist-F \& Divisional-in-Charge of Entomology Division (A), Zoological Survey of India, Kolkata and Dr. Gaurav Sharma, Officer-in-Charge, Hymenoptera Section, Zoological Survey of India, Kolkata for providing facilities and encouragements. 

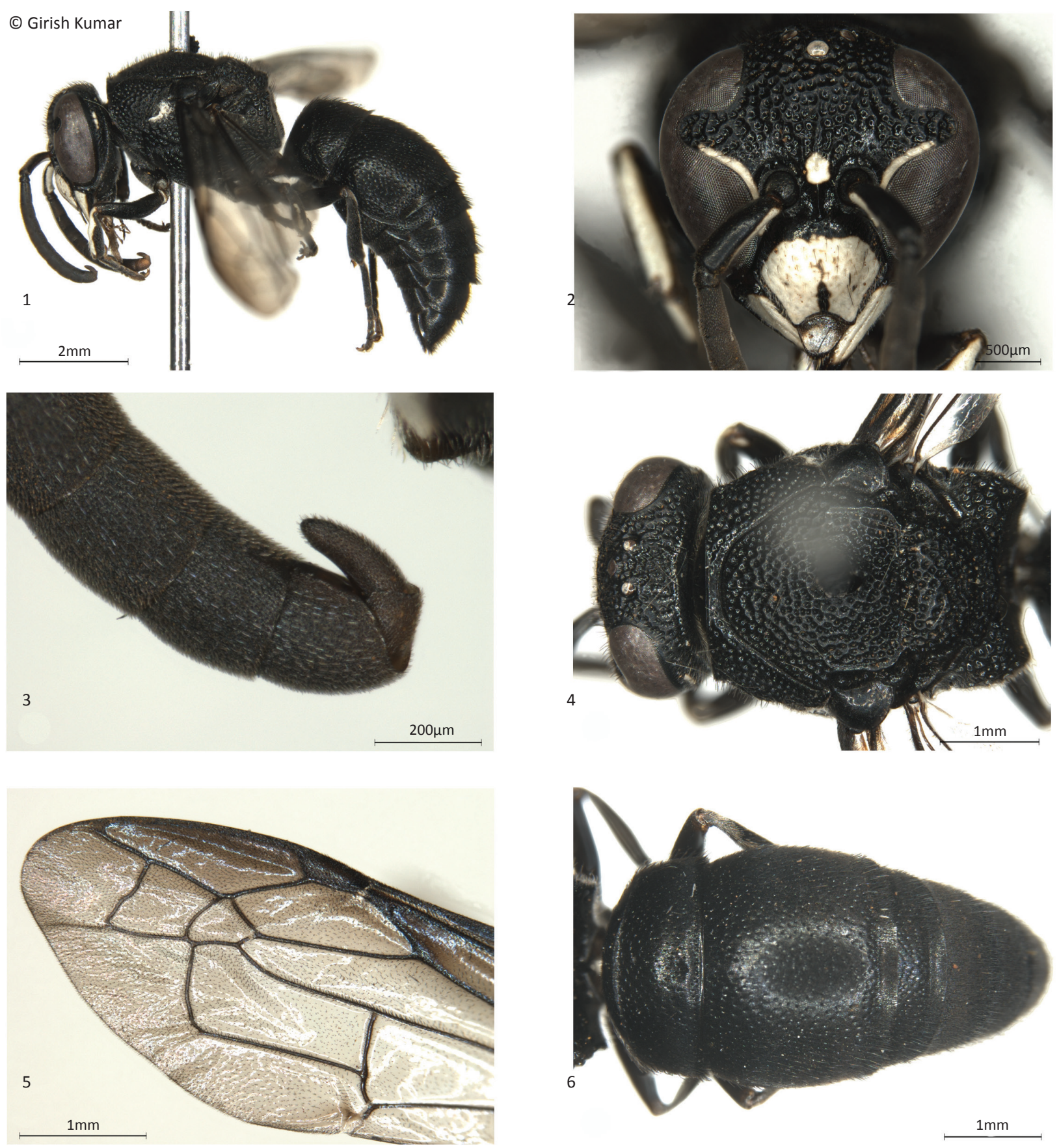

Images 1-6. Lissodynerus rutlandicus sp. nov. (male) (Holotype NZC 14878/H3).

1 - Body profile; 2 - Head frontal view; 3 - Apical antennal articles; 4 - Head \& mesosoma dorsal view; 5 - Apical half of forewing;

6 - Metasoma dorsal view

absent; frons and vertex closely, strongly and uniformly punctured, diameter of punctures greater than interspaces; metanotum strongly convex, not gibbous in the middle; base of S2 flat, not furrowed longitudinally; apical antennal article hook-like, somewhat slender and slightly curved; body with strong erect black setae.

Description: Holotype Male (Image 1): Body length
$(\mathrm{H}+\mathrm{M}+\mathrm{T} 1+\mathrm{T} 2) 7 \mathrm{~mm}$; forewing length $7 \mathrm{~mm}$. Body black with white and yellowish-brown to blackish-brown markings. White markings: mandible except lateral and apical portions, a broadly rounded mark on labrum, clypeus except basal and lateral margins and a narrow vertical median line on lower half, interantennal spot, a narrow line on inner margin of eye from base of clypeus 
to the ocular sinus, a linear mark on temple near to outer eye margin, ventral face of scape, outer side of fore tibia, outer side of mid tibia faintly, a long mark on outer side of fore basitarsus. Yellowish-brown to blackish-brown markings: maxillary and labial palpus, apex of mandible, ventral side of $11^{\text {th }}$ and $12^{\text {th }}$ antennal articles, apical tarsal segment and claws of all legs. Wings almost hyaline; forewing slightly infumated along anterior margins; stigma blackish-brown; veins dark brown. Apical lamellae of T2-T5 brown. Body with strong erect black setae, the length of setae in average equal to the distance between anterior and posterior ocellus.

Head: 1.09x as wide as long in front view (Image 2); clypeus convex, the extreme apex with two teeth, the area in between them deeply emarginated, the distance between teeth distinctly less than the distance between anterior tentorial pits, maximum width of clypeus $1.43 \mathrm{x}$ its length medially, with weak punctures; frons and vertex densely, strongly and uniformly punctured, diameter of punctures greater than interspaces; upper half of temple strongly punctured, lower half sparsely punctured, area towards occipital carina almost smooth; POL 1.18x OOL (Image 4); diameter of anterior ocellus about as long as the distance between anterior ocellus and posterior ocelli; temple $0.50 x$ as wide as eye in profile (measured through its ocular sinus); interocular distance $1.22 x$ greater on vertex than at clypeus; occipital carina complete and narrowed ventrally. Antennal scrobe $4 x$ farther from each other than from eyes, granulately punctured; apical antennal article hook-like (Image $3)$, reaching to the basal margin of eleventh article, somewhat slender and slightly curved.

Mesosoma (Image 4): Anterior face of pronotum smooth without fovea; pronotal carina strong and complete; posterior face and lateral sides of pronotum, mesoscutum and scutellum strongly and densely punctate, diameter of punctures greater than interspaces; median length of mesoscutum $0.88 \mathrm{x}$ its maximum width; metanotum strongly convex, not gibbous in the middle, with its posterior face comes as a part of the posterior face of mesosoma, punctures strong except at posterior area smooth; mesopleuron densely punctured except large area of epicnemium and posterior margin smooth; epicnemial carina present, a line of strong punctures present just below the posterior half of epicnemial carina; upper metapleuron with few strong punctures and transverse striations at upper half, lower metapleuron almost smooth. Propodeum vertical, dorsal side of propodeum with largest rugose punctures, upper carina of propodeum absent, median area of propodeum concave, smooth except punctures on outer sides, median carina complete, lateral side of propodeum with strong punctures and few strong transverse striations; submarginal carina not projecting as rounded lobe above propodeal valvula. Tegula smooth, not evenly rounded posteriorly, emarginate adjoining parategula; parategula surpassing apex of tegula; axillary fossa narrower than long. Forewing (Image 5) with second submarginal cell not petiolate, first and second recurrent veins both received in submarginal cell II.

Metasoma (Images 6): T1 with regular and strong transverse carina, anterior vertical surface with sparse minute punctures, dorsal surface with uniform punctures, diameter of punctures on median area less than interspaces, lateral sides with dense punctures, maximum width of T1 2.14x its length in dorsal view; T1 $0.90 x$ as wide as T2; T2 $0.81 x$ as long as wide in dorsal view; punctures on median area of T2 uniformly sculptured, diameter of punctures less than interspaces, but coarser than that of $\mathrm{T} 1$, lateral sides and posterior margin near apical lamella with dense punctures; S2 with distinct and strong punctures; $\mathrm{T} 1$ with a very narrow apical lamella; T2-T5 with broad, thick, opaque apical lamella, with almost uniform width at the sides and at the middle; base of S2 flat, not furrowed longitudinally.

\section{Female}

Unknown.

\section{Etymology}

The species is named after the locality (Rutland Island) where the holotype was collected.

\section{Discussion}

This new species comes close to Lissodynerus septemfasciatus (Smith, 1858) and is particularly similar to the subspecies Lissodynerus septemfasciatus feanus (Soika, 1941), in having an apical lamella on T5; apical lamellae of tergites with uniform width laterally and dorsally; metanotum strongly convex; base of S2 flat, without longitudinal groove; apical antennal segment slender and slightly curved; and metasoma entirely black. It runs towards this species in the key of Soika (1994) (except the colour characters in couplet number 6), but it distinctly differs from $L$. septemfasciatus in having: (1) Punctation on T2 coarser (in L. septemfasciatus punctation on T2 much less coarse); (2) Male clypeus deeply emarginate at apex (in L. septemfasciatus male clypeus very shallowly emarginate); (3) T1 with strongly produced transverse carina (in L. septemfasciatus T1 with regular thin carina); and (4) Mesosoma and metasoma 
entirely black (in L. septemfasciatus mesosoma and metasoma with strong yellow maculations except in $L$. septemfasciatus feanus with mesosoma almost entirely black).

It may be noted that in Giordani Soika's (1994: p. 4) key to genera, Lissodynerus is distinguished at couplet four by having well-developed apical lamellae on T1-T2, however the first couplet of his species key (p. 302) has as the first alternative that only $\mathrm{T} 2-\mathrm{T} 3$ are lamellate. In a female specimen of $L$. septemfasciatus septemfasciatus in the American Museum of Natural History a lamella is poorly developed, but it is well developed in a female and male of $L$. solomon. The distribution of metasomal lamellae is evidently not a generic character in Lissodynerus as the species are variable.

\section{Taxonomic account of the genus Lissodynerus Soika,} 1993

Soika (1973) used the name Lissodynerus as a generic name for Odynerus septemfasciatus var. feanus Soika, 1941. The author used this generic name, without giving any characters differentiating the taxon, in the description of the male of this subspecies, after having seen it as a manuscript name in a collection and without checking whether it had been published. So, this name was unavailable under Article 13.1.1 of the present International Code of Zoological Nomenclature (van der Vecht \& Carpenter 1990). Soika \& Kojima (1988) used the name Trichodynerus as a generic name in the combination Trichodynerus agilis cursor Soika \& Kojima, 1988. The authors used this generic name, without giving any characters differentiating the taxon, in the description of a new subspecies, while stating that it had not been published. Therefore this name was also unavailable under Article 13.1.1 of the Code (van der Vecht \& Carpenter 1990). Soika (1993) first validly published Lissodynerus, designating Odynerus septemfasciatus Smith, 1857, as the type species, and making reference to Lissodynerus Soika (1973). Subsequently, Soika 1994 (1993), redescribed Lissodynerus as a "new genus" based on the type species Odynerus septemfasciatus Smith, 1857.

\section{Checklist of world species of Lissodynerus Soika, 1993} 1. L. agilis (Smith, 1859)

1a. L. agilis agilis (Smith, 1859) - Indonesia: Moluccas, Papua.

1b. L. agilis cursor Soika \& Kojima, 1988 - Papua New Guinea.

1c. L. agilis multifasciatus Soika, 1994 - Papua New Guinea: Bismarck Islands. 1d. L. agilis novaeguineae (Soika, 1941) - Indonesia: Papua; Papua New Guinea.

1e. L. agilis postremus Soika, 1994 - Papua New Guinea: Bismarck Islands.

2. L. ater Soika, 1994

2a. L. ater ater Soika, 1994 - Solomon Islands.

2b. L. ater emifasciatus Soika, 1994 - Solomon Islands.

3. L. desaussurei Borsato, 2003 - Australia: Queensland.

4. L. impulsus (Smith, 1865) - Indonesia: Moluccas.

5. L. kurandensis Soika, 1994 - Australia: Queensland.

6. L. laminiger (Gribodo, 1892)

6a. L. laminiger laminiger (Gribodo, 1892) - Malaysia (including Sarawak, Sabah); Singapore; Indonesia: Sumatra, Java, Kalimantan.

6b. L. laminiger ruficauda Soika, 1994 - Malaysia: Sabah.

7. L. nigripennis Soika, 1993 - Indonesia: Papua.

8. L. niveatus Soika, 1994 - Philippines.

9. L. pallidus Soika, 1994 - Philippines.

10. L. philippinensis (von Schulthess, 1913) - Philippines.

11. L. rutlandicus Kumar, Srinivasan \& Carpenter sp. nov. - India: South Andaman (Rutland Island).

12. L. septemfasciatus (Smith, 1858)

12a. L. septemfasciatus feanus (Soika, 1941) - Myanmar; Vietnam; Malaysia.

12b. L. septemfasciatus flavithorax Soika, 1994 Indonesia: Sumatra.

12c. L. septemfasciatus septemfasciatus (Smith, 1858) - India: Karnataka; Malaysia (including Sarawak); Indonesia: Sumatra; Java.

13. L. simillimus Soika, 1994 - Solomon Islands.

14. L. solomon Soika, 1993 - Papua New Guinea: Bismarck Islands; Solomon Islands.

15. L. trilaminatus Soika, 1994 - Indonesia: Moluccas.

16. L. vespoides (Williams, 1919) - Philippines.

17. L. wilhelmi Soika, 1996 - Papua New Guinea.

\section{REFERENCES}

Soika, A.G. (1973). Descrizione di nuovi Eumenidi. Bollettino del Museo Civico di Storia Naturale di Venezia 24: 97-131.

Soika, A.G. (1993). Contributo alla conoscenza degli Eumenidi dell'Australia e della Nuova Guinea (Hym. Vespoidea). Bollettino del Museo Civico di Storia Naturale di Venezia 42: 125-149.

Soika, A.G. (1994). Ricerche sistematiche su alcuni generi di Eumenidi della Regione Orientale e della Papuasia. Annali del Museo Civico di Storia Naturale "G. Doria" 90: 1-348.

Soika, A.G. \& J. Kojima (1988). Eumeninae wasps collected in Papua New Guinea by J. Kojima (Hymenoptera, Vespidae). Bollettino del Museo Civico di Storia Naturale di Venezia 38: 175-182.

Vecht, J. van der \& J.M. Carpenter (1990). A catalogue of the genera of the Vespidae (Hymenoptera). Zoologische Verhandelingen, Leiden 260: 1-62. 